\title{
Calls to conserve biodiversity hotspots
}

Last week's announcement that dozens of new species had been found in remote Indonesia has led to fresh calls to protect biodiversity. A team of scientists from Indonesia, Australia and the United States announced their findings on 7 February, and hope that their eyecatching photos of never-before seen plants and animals will put pressure on Indonesia to take care of its natural bounty.

The Foja mountains, an isolated area on the western side of New Guinea, became famous in 1981, when biologist and author Jared Diamond found a long-lost species there, the golden-fronted bowerbird. Scientists funded by the non-profit group Conservation International returned to the region in November. What they discovered as they surveyed 300,000 hectares of pristine forest and 750,000 hectares of nearly untouched land surpassed their expectations.

They found what they believe are twenty new species of frogs, four new butterflies and five new palms. And those who ventured to the top of the mountain in a helicopter found a bizarre red-faced and wattled honeyeater bird". The male Berlepsch's six-wired bird of paradise, never before seen by Western scientists, put on a display for a female that convinced the team that it is a separate species, not just a new subspecies as previously thought.

Finding so much unknown biodiversity is a rare event, which some conservationists say happens only every few decades. Others compare the find to the discovery of tens of frog species in Sri Lanka in 2002 or the discovery of three new mammals in Vietnam in the 1990s.

The main scientific significance is that it may be easier than previously thought for clusters of unique species to arise.

The area used to be an arc of "Just because Google islands, pushed up over time into an isolated mountain range, so scientists were optimistic about finding endemic species there. But Foja is much smaller than other areas where Earth gives us satellite images, we should not feel that our world is fully explored."

this has occurred, such as the highlands of the Bird's Head Peninsula to the west and the Huon Peninsular to the southeast. "Our study has shown that the 'ittle' Foja mountains are big enough to constitute a significant area of species endemism," says Bruce Beehler, a Conservation International scientist who led the trip.

Beehler and others want similar investigations to be carried out elsewhere in New Guinea, as well as stretches of the Congo and Amazon basins. "It confirms my view that

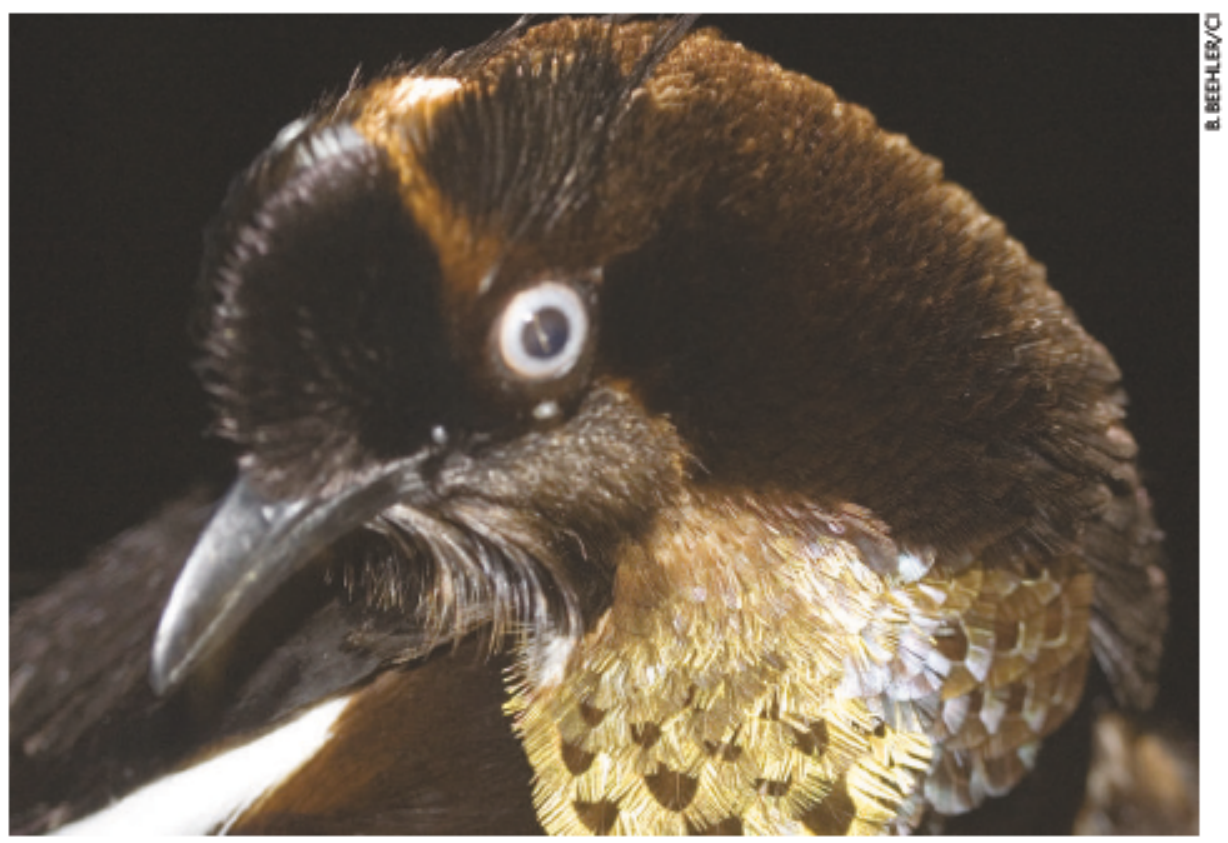

Lost and found: the Berlepsch's six-wired bird of paradise has been rediscovered in Indonesia.

there is still much to be discovered and conserved," says Scott Zona, a palm specialist at the Fairchild Tropical Botanic Garden in Coral Gables, Florida. "Just because Google Earth serves up satellite images of the planet, we should not feel that our world is fully explored."

The scientists realize that analysis of the calls, colours, ecology, description and DNA of their specimens will be needed to convince the scientific world of their findings. Beehler says that the birds, butterflies, plants and frogs discovered are for the most part "clear and unambiguous", but that further work will be needed to clarify the taxonomic status of the mammals.

The palms will also require "painstaking comparisons with known species", says Zona. But the results will be worth it, especially if, as suspected, one is a new species of a rare genus (Pholidocarpus) only known in Thailand, Malaysia and western Indonesia. "I am hungry for more details," he says.

Another expedition scheduled for the dry season later this year should find even more species, says Yance de Fretes, an Indonesian tropical ecologist at Conservation International, as the constant rain in December made it difficult to find mammals and butterflies.

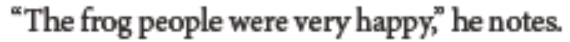

But the headlines could attract not just scientific attention but also poachers. According to Asep Purnama, director of the conservationist group ProFauna Indonesia, the country has a vigorous illegal trade in rare and endangered species - especially orangutans, leaf monkeys and parrots - thought to be worth a staggering US $\$ 900$ million every year.

De Fretes admits that tradesmen might be able to rent a helicopter and pay locals to get access. But he says this is all the more reason to report the species to those who could protect them. "It is important to get the information to the decision-makers," he says. "We need to show how important it is to conserve this area."

For Indonesian scientists such as Johanis Mogea, a plant biologist at the Indonesian Institute of Sciences who discovered four new species of palm, the trip was a rare chance to see their own country's bounty. Conservation isn't normally a priority, he says. "Usually Indonesian scientists don't have enough money."

Indonesia does not have a great record of conservation, as massive deforestation has cut into its biodiversity. But this week Indonesia's president Susilo Bambang Yudhoyono asked the team's leaders to present their case, de Fretes says. If the international media frenzy over the 'lost world' doesn't get his attention, the scientists have another card up their sleeves: they have offered to name one of the new species of butterfly after his wife.

David Cyranoski 